\title{
Solid Fraction of Digestate from Biogas Plant as a Material for Pellets Production
}

\author{
Wojciech Czekała (D)
}

\section{check for}

updates

Citation: Czekała, W. Solid Fraction of Digestate from Biogas Plant as a Material for Pellets Production. Energies 2021, 14, 5034. https:// doi.org/10.3390/en14165034

Academic Editor: Wei-Hsin Chen

Received: 21 July 2021

Accepted: 13 August 2021

Published: 17 August 2021

Publisher's Note: MDPI stays neutral with regard to jurisdictional claims in published maps and institutional affiliations.

Copyright: (C) 2021 by the author. Licensee MDPI, Basel, Switzerland. This article is an open access article distributed under the terms and conditions of the Creative Commons Attribution (CC BY) license (https:/ / creativecommons.org/licenses/by/ $4.0 /)$.
Department of Biosystems Engineering, Poznań University of Life Sciences, Wojska Polskiego 50, 60-627 Poznań, Poland; wojciech.czekala@up.poznan.pl

\begin{abstract}
One of the anaerobic digestion process products in an agricultural biogas plant is digestate (digested pulp). Large quantities of digestate generated in the process of biogas production all over the world require proper management. Fertilization is the main management of this substrate, so it is essential to look for new alternatives. The work aims to determine and discuss the possibilities of using digestate solid fraction (DSF) for pellets as biofuel production. Pellets from DSF alone and pellets with sawdust, grain straw additives were analyzed. The lower heating value (LHV) based on the dry matter for all analyzed pellets ranged from $19,164 \mathrm{~kJ} \cdot \mathrm{kg}^{-1}$ to $19,879 \mathrm{~kJ} \cdot \mathrm{kg}^{-1}$. The ash content was similar for all four samples and ranged from $3.62 \%$ to $5.23 \%$. This value is relatively high, which is related to the degree of fermentation in the anaerobic digestion process. The results showed that the DSF substrate after the anaerobic digestion process still has energy potential. Analyzing those results, it seems that DSF can be a highly valuable substrate for solid biofuels production.
\end{abstract}

Keywords: renewable energy; waste to energy; biomass; biofuels; solid biofuels; circular economy

\section{Introduction}

The depletion of fossil fuels is one of the main reasons for interest in renewable energy sources [1,2]. The second most important factor is the legal regulations related to environmental protection [3]. One of the renewable energy sources are biofuels produced from biomass [4,5]. Depending on the physical state of the final product, it is possible to distinguish solid [6,7], liquid [8], and gaseous biofuels [9,10]. One of the gaseous fuels is biogas, a mixture of gases produced by anaerobic digestion of biomass and organic waste [11,12]. Its main component is methane, which is a combustible gas $[13,14]$.

Agricultural and agri-food processing waste are often used for the agricultural biogas production (Figure 1). Moreover, many other substrates can be used for biogas production $[15,16]$. Only part of all substrates is decomposed by anaerobic digestion, where biogas is the main product [17]. Another product, undecomposed residue of the anaerobic digestion process, is digestate (digested pulp) [18,19]. Digestate compositions include irreducible organic compounds, non-degradable mineral compounds, and the biomass of living organisms. Its quantity and composition depend on many factors, such as the type of substrate, fragmentation degree, and physical and chemical properties [20]. After obtaining digested pulp, this material has to be properly managed [21,22]. In Europe, the most popular method of its management is direct use for fertilization purposes [23]. In Poland, often people do not know what the properties of digestate are (although it changes) [24].

The production of solid biofuels can be a suitable alternative [25,26]. It is necessary to demonstrate the advantages of using a solid fraction of digested pulp as an alternative solid [27] and gaseous fuel [28]. In case of appreciation of its specific characteristics, it is possible to process it [29]. This represents a reason to develop the required kinds of management and will also bring economic benefits. One way to process the digestate is its separation [30] on a minimum of two fractions, solid and liquid. After receiving the solid 
fraction, consisting of undegraded anaerobic digestion organic matter, the process may be prepared for solid biofuel.

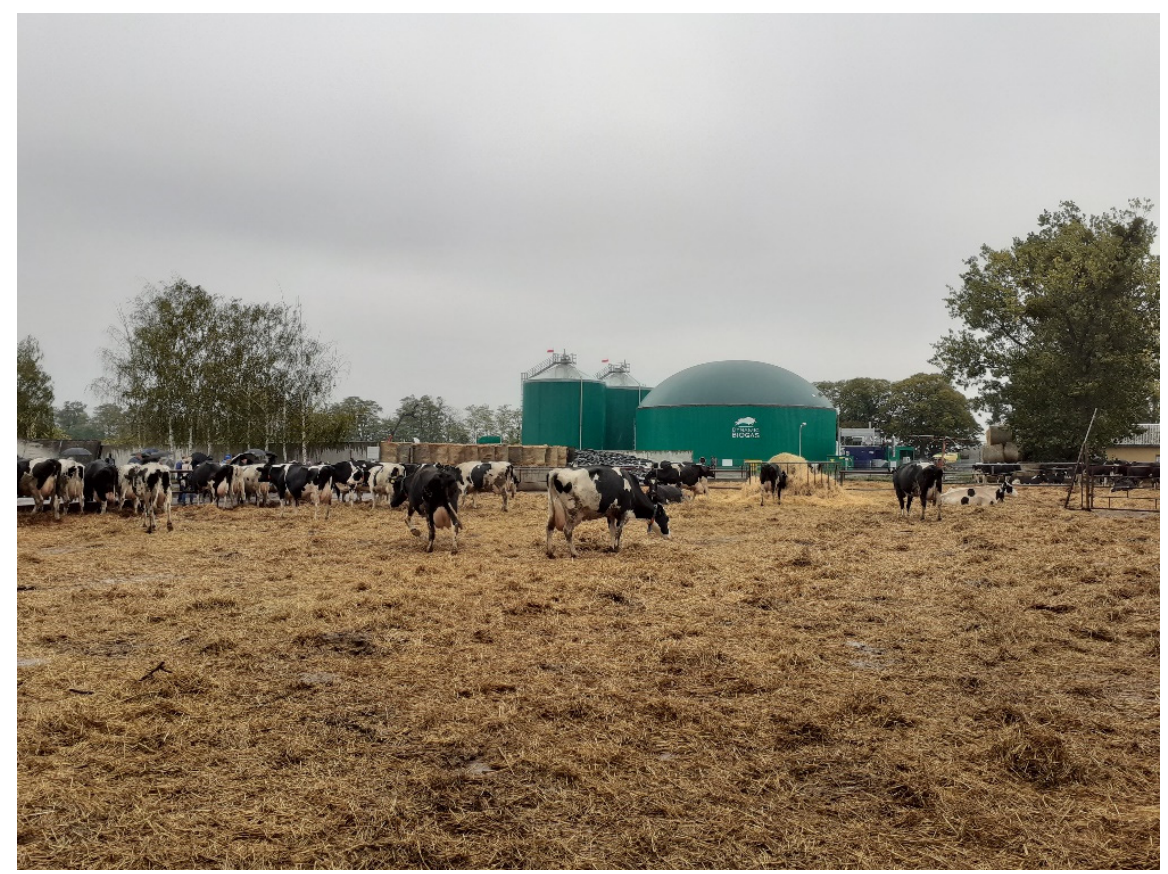

Figure 1. Agricultural biogas plant.

Sawdust is most commonly used for pellet production in Europe. It is very important to determine the applicability of alternative substrates. Only a few studies reported potential methods for managing solid fraction of digestate in waste to energy technology, especially for solid biofuels. The novelty of this work is that some materials such as a solid fraction of digestate can be used as an alternative substrate to solid biofuels production. Fertilization is the main management of this substrate, so it is essential to look for new alternatives.

The work aims to determine and discuss the possibilities of using DSF for pellets as biofuel production. The parameters used in order to determine the formulated research task were a higher heating value, lower heating value, and cost of pellets production for DSF pellet and three other blends.

\section{Materials and Methods}

\subsection{Substrates and Composition of Mixtures}

The main substrate used for the study was the DSF from one of the typical agricultural biogas plants in Poland (Figure 2). The feedstock of the biogas plant was agri-food waste, manure, and slurry. The material was separated and, after that, dried using an industrial belt dryer. The initial parameters of DSF were: dry matter $85 \%$ and organic matter $91 \%$. Straw and sawdust additives were used in the production process of pellets from DSF. The composition of pelleted mixtures is shown in Table 1.

Table 1. Composition of blends used for the production of solid biofuels.

\begin{tabular}{cccc}
\hline \multirow{2}{*}{ Name } & \multicolumn{3}{c}{ \% of the Fresh Matter } \\
\cline { 2 - 4 } & DSF & Grain Straw & Sawdust \\
\hline Blend 1 & 66.7 & 33.3 & - \\
Blend 2 & 66.7 & - & 33.3 \\
Blend 3 & 66.6 & 16.7 & 16.7 \\
DSF & 100.0 & - & - \\
\hline
\end{tabular}




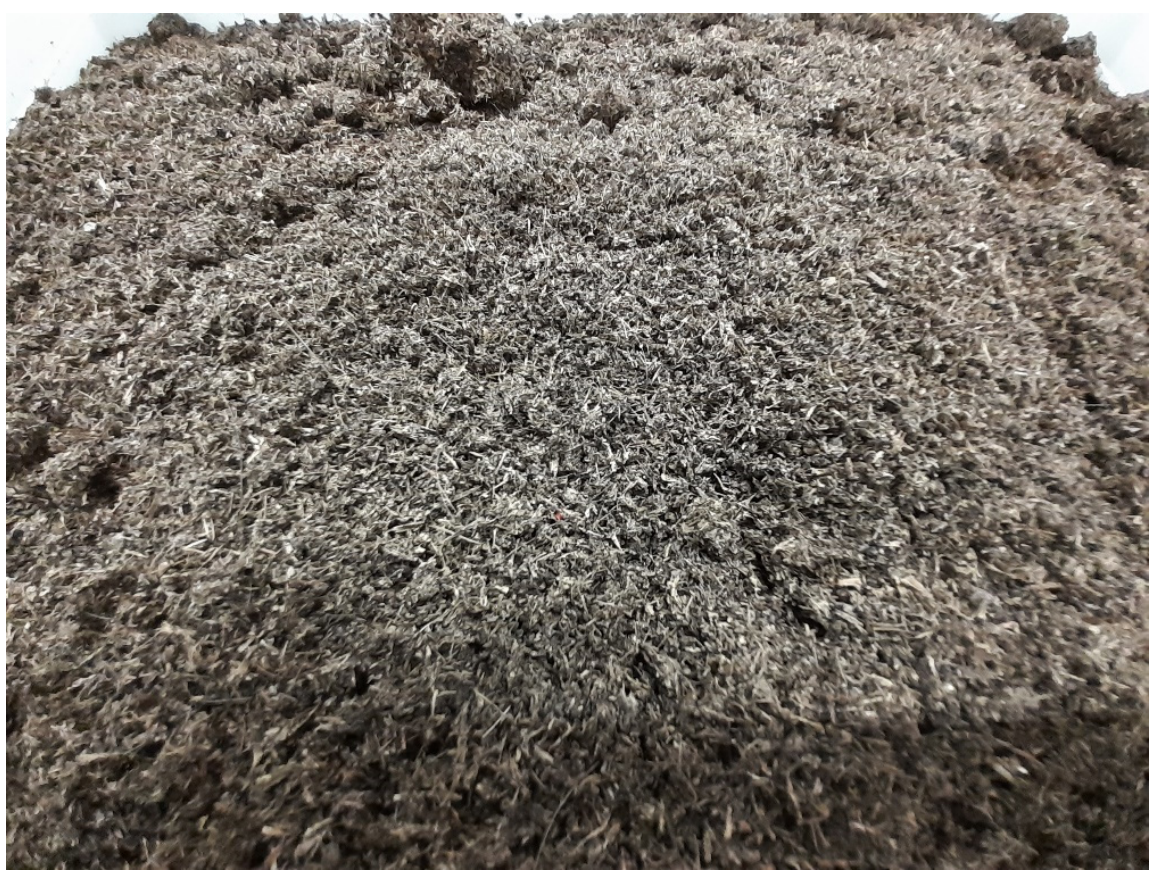

Figure 2. Digestate solid fraction.

\subsection{Pellets Production}

In the process of pellet production, there were three steps which were needed: drying, grinding, and pressing (pelleting process) of the substrate. All tested substrates were characterized by an MC value from 8 to $20 \%$. This range was determined as optimal on the basis of earlier research. MC over $20 \%$ reduces the efficiency of the process. In cases when the $\mathrm{MC}$ is below $8 \%$, forming problems may occur. The straw required fragmentation and this process was conducted using the TALEX-BAK shredder $(7.5 \mathrm{~kW})$. Compaction of substrates was performed by using a pelletizer SJ-25 constructed by the BRIKOL company. The pelletizer has a power of $15 \mathrm{~kW}$ and its capacity is $180 \mathrm{~kg} \cdot \mathrm{h}^{-1}$. The diameter of the entire matrix was $250 \mathrm{~mm}, 6 \mathrm{~mm}$ for a single hole. The maximum length of one single pellet was $35 \mathrm{~mm}$. After producing the solid biofuel, the product has been cooled to maintain the strength parameters. The cost of biofuel production was estimated based on the adapted methodology of [31]. The scheme of the research methodology was presented on Figure 3.

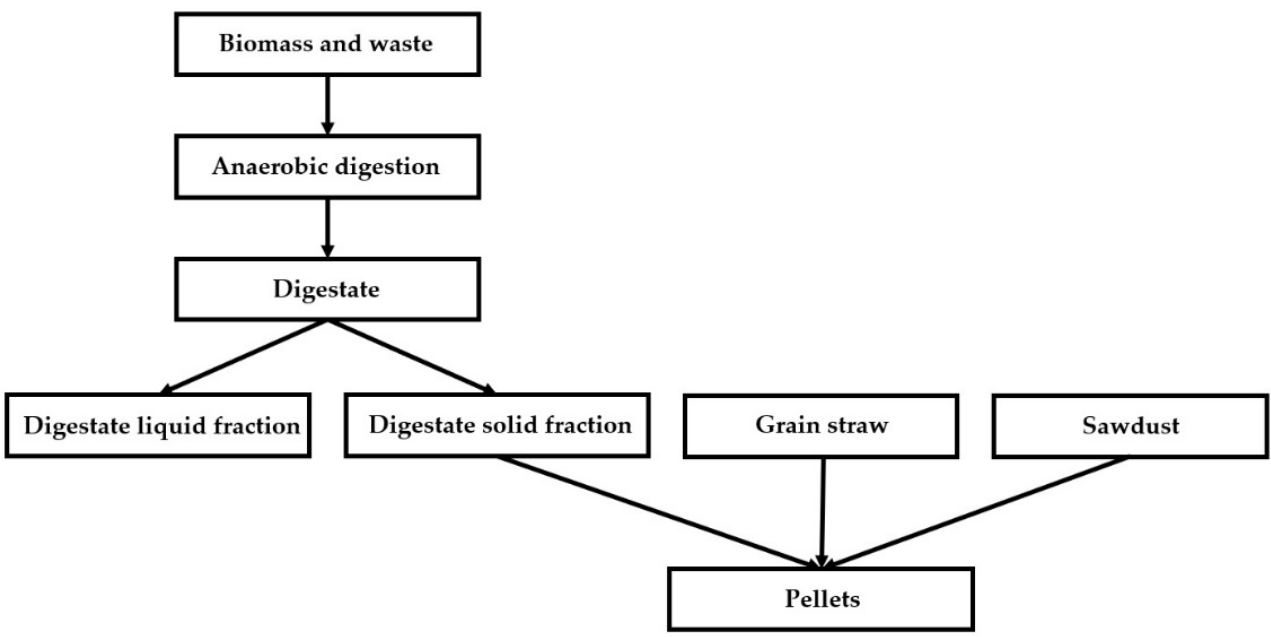

Figure 3. The scheme of the research methodology. 


\subsection{Methods}

The measurement of the DM was performed using a laboratory dryer. Pellets have been drying at the temperature of $105^{\circ} \mathrm{C}$ for $24 \mathrm{~h}$. The MC was checked immediately after the compression process. Organic matter was determined using the muffle furnace at a temperature of $550{ }^{\circ} \mathrm{C}$ in three hours. Each measurement was performed in triplicate.

The HHV was examined using KL-12Mn calorimeter according to the norm established by [32]. The measurement of the HHV was based on complete combustion of the substrate sample placed in a calorimeter, and it was performed in pure oxygen conditions. The HHV was investigated in the four samples: the DSF and three other blends (Table 1). In order to convert the HHV into LHV (where LHV is HHV reduced by the value needed for water to evaporate), the measurement of the humidity has been conducted by using a laboratory dryer in accordance with the norm of [33]. Using the formulas (1) and (2), the values of the energetic parameter were determined.

$$
\mathrm{Q}^{\mathrm{a}}{ }_{\mathrm{s}}=\left(\mathrm{C}\left(\mathrm{D}_{\mathrm{t}}-\mathrm{k}\right)-\mathrm{c}\right) \cdot \mathrm{m}^{-1}
$$

where:

$\mathrm{Q}_{\mathrm{s}}^{\mathrm{a}}$ - combustion heat of the analyzed fuel (HHV) $\left[\mathrm{kJ} \cdot \mathrm{kg}^{-1}\right]$,

$\mathrm{C}$-calorimeter heat capacity $\left[\mathrm{J} \cdot{ }^{\circ} \mathrm{C}^{-1}\right]$,

$\mathrm{D}_{\mathrm{t}}$ - the overall temperature rise of the main period $\left[{ }^{\circ} \mathrm{C}\right]$,

$\mathrm{k}$-correction for environmental heat exchange $\left[{ }^{\circ} \mathrm{C}\right]$,

c-correction sum for the additional heat effects [J],

$\mathrm{m}$-fuel sample mass $[\mathrm{g}]$.

$$
\mathrm{Q}^{\mathrm{a}}{ }_{\mathrm{w}}=\mathrm{Q}^{\mathrm{a}}{ }_{\mathrm{s}}-24.42\left(\mathrm{~W}^{\mathrm{a}}-8.94 \mathrm{H}^{\mathrm{a}}\right)
$$

where:

$\mathrm{Q}^{\mathrm{a}}{ }_{\mathrm{w}}$-calorific value of the analyzed fuel in the analytical state (LHV) $\left[\mathrm{kJ} \cdot \mathrm{kg}^{-1}\right]$,

$\mathrm{Q}_{\mathrm{s}}^{\mathrm{a}}$ - combustion heat of the analyzed fuel (HHV) $\left[\mathrm{kJ} \cdot \mathrm{kg}^{-1}\right]$,

$\mathrm{W}^{\mathrm{a}}$-moisture content of test sample [\%],

$\mathrm{H}^{\mathrm{a}}$-hydrogen content of test sample [\%].

\section{Results and Discussion}

\subsection{Pellets Production and Physical Analysis}

The pellet production process ran correctly, and there were no undesirable cases during the forming. The length of a single pellet was usually $25-35 \mathrm{~mm}$ (Figure 4). The obtained pellets were separated and only $9 \%$ (calculation on weight) of the fuel was shorter than $12 \mathrm{~mm}$ for all tests. According to [34], pellet stability is influenced by optimum moisture content. The obtained results are characterized by relatively high moisture content. The moisture content of the pellets was the most diverse parameter and was at the level of $10.80 \%$ in the DSF pellet to $23.96 \%$ in Blend 1 . In parallel, the ash content ranged from $3.62 \%$ (Blend 2) to $5.23 \%$ (DSF pellet). These values are relatively high. For example, Strandberg et al. [35] has achieved values of $2.2 \%$ and $4.3 \%$ for poplar pellets and wheat straw pellets, respectively.

\subsection{Higher and Lower Heating Value of Pellets}

The HHV and LHV were examined in four samples (Table 1). The LHV based on a dry matter for all four solid biofuels was similar and ranged from $19,164 \mathrm{~kJ} \cdot \mathrm{kg}^{-1}$ to $19,879 \mathrm{~kJ} \cdot \mathrm{kg}^{-1}$. Comparatively, four pellets were produced on the basis of the DSF. The smallest value was characterized by Blend 3 produced from DSF, straw and sawdust, and the biggest value was for Blend 1 as a product of the DSF and straw. The lower heating value of the DSF as a monosubstrate was $19,394 \mathrm{~kJ} \cdot \mathrm{kg}^{-1}$, and it was lower than Blend 1 and 2. The higher heating value $-21,774 \mathrm{~kJ} \cdot \mathrm{kg}^{-1}$ was obtained from pellets prepared with DSF and straw (Table 2). 


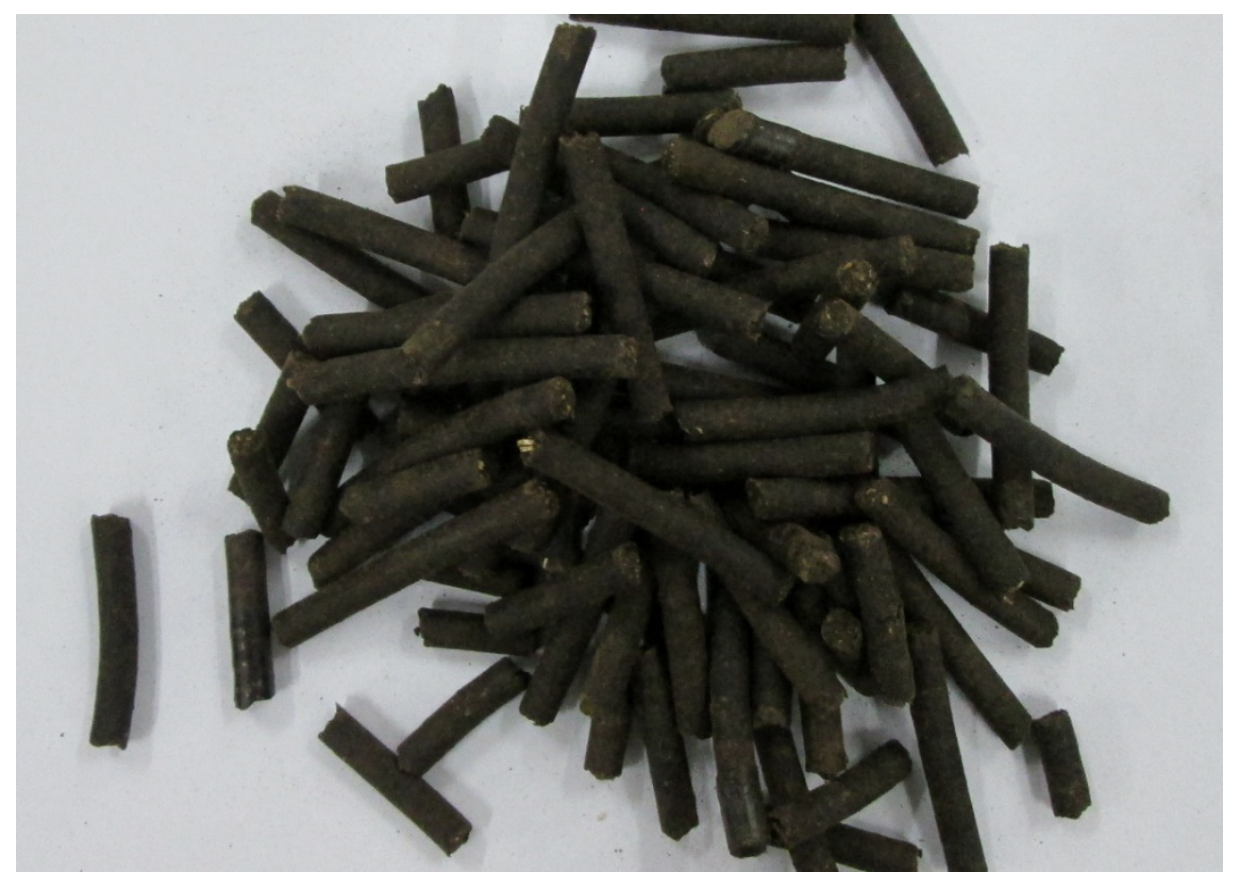

Figure 4. Pellets produced in the granulation process.

Table 2. Properties of solid biofuels.

\begin{tabular}{ccccc}
\hline & \multicolumn{4}{c}{ Parameters } \\
\cline { 2 - 5 } Name & MC [\%] & MM [\%] & $\begin{array}{c}\text { HHV } \\
{\left[\mathbf{k J} \cdot \mathbf{k g}^{-\mathbf{1}} \mathbf{~ D M ]}\right]}\end{array}$ & $\begin{array}{c}\mathbf{L H V} \\
{\left[\mathbf{k J} \cdot \mathbf{k g}^{-\mathbf{1}} \mathbf{~ D M ]}\right.}\end{array}$ \\
\hline Blend 1 & 23.96 & 4.24 & 21,774 & 19,879 \\
Blend 2 & 20.06 & 3.62 & 21,562 & 19,777 \\
Blend 3 & 20.84 & 4.08 & 20,968 & 19,164 \\
DSF & 10.80 & 5.23 & 20,967 & 19,394 \\
\hline
\end{tabular}

Sawdust is commonly used for pellet production [36]. In addition, all types of straw are also popular [37]. Bearing in mind the growing demand for pellets associated with air protection regulations, alternative substrates are expected. It is important that these substrates could be used to produce solid biofuels alone or with the addition of straw and sawdust. In research [38], HHV for forest residues was $19.81 \mathrm{MJ} \cdot \mathrm{kg}^{-1}$. However, for agricultural residues, including straw, it was $18.92 \mathrm{MJ} \cdot \mathrm{kg}^{-1}$. Insofar as research about HHV and LHV sawdust and straw often occurs in the literature, for DSF these studies are just beginning to gain importance.

Results of this study can be compiled with García et al. [39,40]. The fact is that the biofuels from analyzed DSF with or without additives have a similar, sometimes even higher HHV than typical waste and residues from the wood industry and agriculture.

Similar studies were conducted by Kratzeisen et al. [41]. The authors have shown that the LHV for the two pellets from DSF was $15.8 \mathrm{MJ} \cdot \mathrm{kg}^{-1}\left(\mathrm{HHV}=17.3 \mathrm{MJ} \cdot \mathrm{kg}^{-1}\right)$ and 15.0 MJ $\cdot \mathrm{kg}^{-1}\left(\mathrm{HHV}=16.4 \mathrm{MJ} \cdot \mathrm{kg}^{-1}\right)$. These values were lower than the values for the four analyzed blends in studies. For Blend 4 (only DSF), HHV was $18.7 \mathrm{MJ} \cdot \mathrm{kg}^{-1}$ for fuel in normal condition. The MC was $9.2 \%$ and $9.9 \%$ and the MM content was $18.3 \%$ and $14.6 \%$. It should be noted that the MC content of samples described in [41] was similar to that of Blend 4 (Table 2). The MM in the samples discussed in the same paper studies was much higher. 


\subsection{Economic Calculation of Solid Biofuels Production}

The methodology of simple economic analysis has been made according to Czekała et al. [31]. The production cost of one Mg of pellets from the DSF calculation amounted to $143 €$. The market price of solid biofuels in Poland ranges from $120 €$ to $250 €$ per Mg. The cost of production in the analyzed example seems to be high. This is due to the fact that the daily production of DSF is relatively low (about $1.5 \mathrm{Mg}$ ), hence the high cost of depreciation of the device. It should be noted that the size and density of pellets make them easier to transport and store compared with other forms of biomass.

\section{Conclusions}

Environmental protection is a related aspect of biofuels production and use. Using biomass for fuel production have a positive impact on the environment. First of all, the reason for this is the reduction of fossil fuel demand. Furthermore, it is possible by producing biofuels to reduce the uncontrolled degradation of biomass. Uncontrolled biomass decompositions can cause environmental degradation. Analyzing those results, it seems that DSF can be a valuable substrate for solid biofuels production. It is important because the renewable energy supporting system, for example, in Poland is low. The results showed that the digestate after the anaerobic digestion process still has energy potential. It should be emphasized that the energetic use of digestate in thermal processes creates a possibility to use that part of the organic matter that has not been decomposed under the conditions of anaerobic digestion. The combination of an anaerobic process with a thermal process significantly increases the efficiency of the substrates used.

The cost of production per $\mathrm{Mg}$ of pellets can be significantly reduced by using additional substrates as sawdust and straw. This could allow more fuel production, which directly impacts reducing the depreciation cost of dryer and separator that are the most expensive components. As the results of HHV and LHV tests have shown, they are similar regardless of the additions used (Table 2). Low production cost and higher calorific value reflect the substantial value of DSF. However, it is also necessary to conduct research on the environmental impact of the combustion of these kinds of biofuels.

Funding: This work was supported by Human Capital Operational Programme, Sub-measure 8.2.2, co-financed by the European Union under the European Social Fund coordinated by Wojciech Czekała within the period of 2012-2013 (PO KL 8.2.2/30-404-12/13) and 2013-2014 (PO KL 8.2.2/30355-13/14). The research project "Scholarship support for doctoral students specializing in majors strategic for Wielkopolska's development". The publication was co-financed within the framework of Ministry of Science and Higher Education programme as "Regional Initiative Excellence" in years 2019-2022, Project No. 005/RID/2018/19.

Institutional Review Board Statement: Not applicable.

Informed Consent Statement: Not applicable.

Data Availability Statement: Not applicable.

Conflicts of Interest: The author declares no conflict of interest.

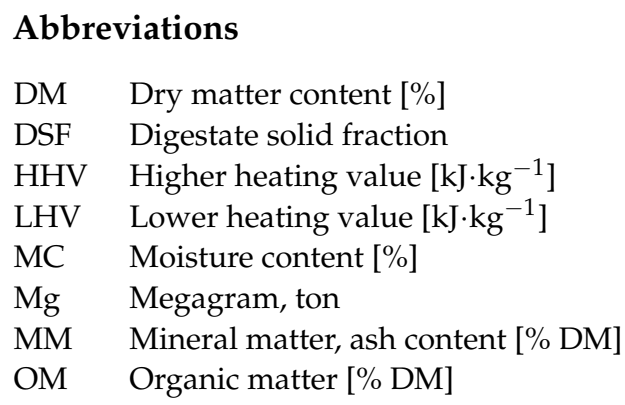




\section{References}

1. Kumar, B.; Bhardwaj, N.; Agrawal, K.; Verm, P.C. Current perspective on pretreatment technologies using lignocellulosic biomass: An emerging biorefinery concept. Fuel Process. Technol. 2020, 199, 106244. [CrossRef]

2. Jastrzębski, K.; Kula, P. Emerging Technology for a Green, Sustainable Energy-Promising Materials for Hydrogen Storage, from Nanotubes to Graphene-A Review. Materials 2021, 14, 2499. [CrossRef] [PubMed]

3. Wang, Y.; Zhi, Q. The Role of Green Finance in Environmental Protection: Two Aspects of Market Mechanism and Policies. Energy Procedia 2016, 104, 311-316. [CrossRef]

4. Castells, B.; Amez, I.; Medic, L.; García-Torrent, J. Torrefaction influence on combustion kinetics of Malaysian oil palm wastes. Fuel Process. Technol. 2021, 218, 106843. [CrossRef]

5. Styks, J.; Knapczyk, A.; Łapczyńska-Kordon, B. Effect of Compaction Pressure and Moisture Content on Post-Agglomeration Elastic Springback of Pellets. Materials 2021, 14, 879. [CrossRef] [PubMed]

6. Williams, O.; Taylor, S.; Lester, E.; Kingman, S.; Giddings, D.; Eastwick, C. Applicability of Mechanical Tests for Biomass Pellet Characterisation for Bioenergy Applications. Materials 2018, 11, 1329. [CrossRef]

7. Mack, R.; Kuptz, D.; Schön, C.; Hartmann, H. Combustion behavior and slagging tendencies of kaolin additivated agricultural pellets and of wood-straw pellet blends in a small-scale boiler. Biomass Bioenergy 2019, 125, 50-62. [CrossRef]

8. Aghilinategh, M.; Barati, M.; Hamadanian, M. Supercritical methanol for one put biodiesel production from chlorella vulgaris microalgae in the presence of $\mathrm{CaO} / \mathrm{TiO} 2$ nano-photocatalyst and subcritical water. Biomass Bioenergy 2019, 123, 34-40. [CrossRef]

9. Padilla-Rivera, A.; Paredes, G.; Güereca, L.P. A systematic review of the sustainability assessment of bioenergy: The case of gaseous biofuels. Biomass Bioenergy 2019, 125, 79-94. [CrossRef]

10. Cudjoe, D.; Han, M.S.; Nandiwardhana, A.P. Electricity generation using biogas from organic fraction of municipal solid waste generated in provinces of China: Techno-economic and environmental impact analysis. Fuel Process. Technol. 2020, $203,106381$. [CrossRef]

11. Dach, J.; Koszela, K.; Boniecki, P.; Zaborowicz, M.; Lewicki, A.; Czekała, W.; Skwarcz, J.; Wei, Q.; Piekarska-Boniecka, H.; Białobrzewski, I. The use of neural modelling to estimate the methane production from slurry fermentation processes. Renew. Sustain. Energy Rev. 2016, 56, 603-610. [CrossRef]

12. Dahunsi, S.O.; Adesulu-Dahunsi, A.T.; Osueke, C.O.; Lawal, A.I.; Olayanju, T.M.A.; Ojediran, J.O.; Izebere, J.O. Biogas generation from Sorghum bicolor stalk: Effect of pretreatment methods and economic feasibility. Energy Rep. 2019, 5, 584-593. [CrossRef]

13. Decker, T.; Baumgardner, M.; Prapas, J.; Bradley, T. A mixed computational and experimental approach to improved biogas burner flame port design. Energy Sustain. Dev. 2018, 44, 37-46. [CrossRef]

14. Mazurkiewicz, J.; Marczuk, A.; Pochwatka, P.; Kujawa, S. Maize Straw as a Valuable Energetic Material for Biogas Plant Feeding. Materials 2019, 12, 3848. [CrossRef]

15. Gava, O.; Favilli, E.; Bartolini, F.; Brunori, G. Knowledge networks and their role in shaping the relations within the Agricultural Knowledge and Innovation System in the agroenergy sector. The case of biogas in Tuscany (Italy). J. Rural Stud. 2017, 56, 100-113. [CrossRef]

16. Woźniak, M.; Ratajczak, I.; Wojcieszak, D.; Waśkiewicz, A.; Szentner, K.; Przybył, J.; Borysiak, S.; Goliński, P. Chemical and Structural Characterization of Maize Stover Fractions in Aspect of Its Possible Applications. Materials 2021, 14, 1527. [CrossRef] [PubMed]

17. Nguyen, V.H.; Topno, S.; Balingbing, C.; Nguyen, V.C.N.; Röder, M.; Quilty, J.; Jamieson, C.; Thornley, P.; Gummert, M. Generating a positive energy balance from using rice straw for anaerobic digestion. Energy Rep. 2016, 2, 117-122. [CrossRef]

18. Czekała, W.; Dach, J.; Dong, R.; Janczak, D.; Malińska, K.; Jóźwiakowski, K.; Smurzyńska, A.; Cieślik, M. Composting potential of the solid fraction of digested pulp produced by a biogas plant. Biosyst. Eng. 2017, 160, 25-29. [CrossRef]

19. Lachman, J.; Baláš, M.; Lisý, M.; Lisá, M.; Milčák, P.; Elbl, P. An overview of slagging and fouling indicators and their applicability to biomass fuels. Fuel Process. Technol. 2021, 217, 106804. [CrossRef]

20. Lindner, J.; Zielonka, S.; Oechsner, H.; Lemmer, A. Effects of mechanical treatment of digestate after anaerobic digestion on the degree of degradation. Bioresour. Technol. 2015, 178, 194-200. [CrossRef] [PubMed]

21. Boni, M.R.; D'Amato, E.; Polettini, A.; Pomi, R.; Rossi, A. Effect of ultrasonication on anaerobic degradability of solid waste digestate. Waste Manag. 2016, 48, 209-217. [CrossRef] [PubMed]

22. Maynaud, G.; Druilhe, C.; Daumoin, M.; Jimenez, J.; Patureau, D.; Torrijos, M.; Pourcher, A.M.; Wéry, N. Characterisation of the biodegradability of post-treated digestates via the chemical accessibility and complexity of organic matter. Bioresour. Technol. 2017, 231, 65-74. [CrossRef] [PubMed]

23. Kataki, S.; Hazarika, S.; Baruah, D.C. Assessment of by-products of bioenergy systems (anaerobic digestion and gasification) as potential crop nutrient. Waste Manag. 2016, 59, 102-117. [CrossRef] [PubMed]

24. Czekała, W.; Lewicki, A.; Pochwatka, P.; Czekała, A.; Wojcieszak, D.; Jóźwiakowski, K.; Waliszewska, H. Digestate management in Polish farms as an element of the nutrient cycle. J. Clean. Prod. 2020, 242, 118454. [CrossRef]

25. Moreira, D.M.; Ferreira, V.; Resende, P.R.; Pinho, C. Determination of kinetic data through the fluidized bed combustion of chars made from vine and kiwi pruning wastes. Energy Rep. 2020, 6, 615-619. [CrossRef]

26. Tan, M.; Luo, L.; Wu, Z.; Huang, Z.; Zhang, J.; Huang, J.; Yang, Y.; Zhang, X.; Li, H. Pelletization of Camellia oleifera Abel. shell after storage: Energy consumption and pellet properties. Fuel Process. Technol. 2020, 201, 106337. [CrossRef] 
27. Czekała, W.; Bartnikowska, S.; Dach, J.; Janczak, D.; Smurzyńska, A.; Kozłowski, K.; Bugała, A.; Lewicki, A.; Cieślik, M.; Typańska, D.; et al. The energy value and economic efficiency of solid biofuels produced from digestate and sawdust. Energy 2018, 159, 1118-1122. [CrossRef]

28. Czekała, W. Biogas Production from Raw Digestate and its Fraction. J. Ecol. Eng. 2019, 20, 97-102. [CrossRef]

29. Musatti, A.; Ficara, E.; Mapelli, C.; Sambusiti, C.; Rollini, M. Use of solid digestate for lignocellulolytic enzymes production through submerged fungal fermentation. J. Environ. Manag. 2016, 199, 1-6. [CrossRef]

30. Lin, L.; Yang, L.; Xu, F.; Michel, F.C.; Li, Y. Comparison of solid-state anaerobic digestion and composting of yard trimmings with effluent from liquid anaerobic digestion. Bioresour. Technol. 2014, 169, 439-446. [CrossRef]

31. Czekała, W.; Bartnikowska, S.; Lewicka, A.; Bugała, A.; Zbytek, Z.; Lewicki, A. Economic and energy efficiency of the solid biofuels produced from digested pulp. MATEC Web Conf. 2016, 60, 04005. [CrossRef]

32. PN-81/G-04513 Polish Standard: Solid Fuels—Determination of Heat of Combustion and Calculation of Calorific Value; Polski Komitet Normalizacji: Miar i Jakości, Poland, 1981.

33. PN-92/P-50092 Polish Standard: Raw Materials for the Paper Industry—Wood—Chemical Analysis; Polski Komitet Normalizacji: Miar i Jakości, Poland, 1992.

34. Whittaker, C.; Shield, I. Factors affecting wood, energy grass and straw pellet durability-A review. Renew. Sustain. Energy Rev. 2017, 71, 1-11. [CrossRef]

35. Strandberg, A.; Thyrela, M.; Skoglund, N.; Lestander, T.A.; Broström, M.; Backman, R. Biomass pellet combustion: Cavities and ash formation characterized by synchrotron X-ray micro-tomography. Fuel Process. Technol. 2018, 176, 211-220. [CrossRef]

36. Peng, J.; Bi, X.T.; Lim, C.J.; Peng, H.; Kim, C.S.; Jia, D.; Zuo, H. Sawdust as an effective binder for making torrefied pellets. Appl. Energy 2015, 157, 491-498. [CrossRef]

37. Ríos-Badrán, I.M.; Luzardo-Ocampo, I.; García-Trejo, J.F.; Santos-Cruz, J.; Gutiérrez-Antonio, C. Production and characterization of fuel pellets from rice husk and wheat straw. Renew. Energy 2020, 145, 500-507. [CrossRef]

38. Stolarski, M.; Graban, Ł.; Szczukowski, S.; Tworkowski, J. Agricultural and forest biomass as feedstock in the manufacture of solid biofuels. Pol. J. Agron. 2010, 2, 67-72. Available online: https://www.iung.pl/PJA/wydane/2/PJA2_12.pdf (accessed on 13 July 2021).

39. García, R.; Pizarro, C.; Lavín, A.G.; Bueno, J.L. Spanish biofuels heating value estimation, Part I: Ultimate analysis data. Fuel 2014, 117, 1130-1138. [CrossRef]

40. García, R.; Pizarro, C.; Lavín, A.G.; Bueno, J.L. Spanish biofuels heating value estimation, Part II: Proximate analysis data. Fuel 2014, 117, 1139-1147. [CrossRef]

41. Kratzeisen, M.; Starcevic, N.; Martinov, M.; Maurer, C.; Müller, J. Applicability of biogas digestate as solid fuel. Fuel 2010, 89, 2544-2548. [CrossRef] 